Tarbawi : Jurnal Pendidikan Islam Vol. 18. No. I. Januari - Juni 202I

p-ISSN: 2088-3102; e-ISSN: 2548-415X

\title{
PEMBELAJARAN DARING MASA PANDEMI COVID-I9 DI SEKOLAH INDONESIA KUALA LUMPUR
}

\author{
Titania Putri Widianti'), Silfiyani Musoffa2), Muhammad Irfan Maulana ${ }^{3)}$, Anik Sri \\ Widayati $^{4}$, Riza Zahriyal Falah ${ }^{5}$ \\ 1,2,3,4,5 Institut Agama Islam Negeri Kudus \\ ${ }^{1}$ kdstania8@gmail.com \\ 2silfiyanimusoffa@gmail.com \\ ${ }^{3}$ maulanairfanmuhammad@gmail.com \\ 4widayatia18@gmail.com \\ 5rizazahriya@gmail.comsari@gmail.com
}

\begin{abstract}
ABSTRAK
Pandemi COVID-19 memberikan dampak yang signifikan dalam dunia pendidikan yaitu adanya transformasi pembelajaran yang semula dilakukan secara konvensional beralih menjadi daring. Tujuan Penelitian ini yaitu 1) Untuk mengidentifikasi bagaimana sistem pembelajaran masa pandemi COVID-19, 2) Untuk mengetahui bagaimana implementasi pembelajaran daring masa pandemi COVID-19 di SIKL, dan 3) Untuk mengetahui kelebihan dan kekurangan dalam pembelajaran daring selama pandemi COVID-19 di SIKL. Penelitian ini menggunakan metode kualitatif, subyek penelitian guru dan kepala sekolah. Pengumpulan data melalui dokumentasi dan wawancara dalam pelaksanaan KKL International Virtual Fieldwork Study di Sekolah Indonesia Kuala Lumpur yang diselenggarakan oleh Institut Agama Islam Negeri Kudus (IAIN Kudus). Hasil dari penelitian menunjukkan bahwa pembelajaran daring dilakukan sebagai upaya belajar di rumah (BDR) guna memutus penyebaran COVID-19 membutuhkan kreativitas guru dan pendampingan orang tua, implementasi pembelajaran daring di SIKL direalisasikan dalam bentuk sistem digital seperti blueprint, program unggulan dan feedback laporan dari orang tua, pembelajaran daring di SIKL memiliki kelebihan dalam hal pelaksanaan sistem digital, program unggulan, serta feedback laporan orang tua dan memiliki kekurangan dalam hal keterbatasan akses internet dan kejenuhan siswa dalam belajar.
\end{abstract}

Kata Kunci: Implementasi, Pembelajaran Daring, COVID-19, SIKL. 
I8 | Tarbawi : Jurnal Pendidikan Islam Vol. 18. No. I. Januari - Juni 202l

\begin{abstract}
The COVID-19 pandemic has a significant impact on world education, namely the transformation of conventional learning into courage. The objectives of this study are 1) To find out how the learning system during the COVID-19 pandemic, 2) To see how the implementation of bold learning to face the COVID-19 pandemic in SIKL, and 3) To see the advantages and disadvantages of learning during the COVID-19 pandemic. at SIKL. This study uses qualitative methods, the subject of research is the teacher and the principal. Collecting data through documentation and interviews in the implementation of the KKL International Virtual Fieldwork Study at the Kuala Lumpur Indonesian School organized by the Kudus State Islamic Institute (IAIN Kudus). The results of the study show that bold learning as an effort to learn at home (BDR) to cut the spread of COVID-19 requires teacher creativity and parental assistance, the implementation of learning in SIKL is realized in the form of a digital system such as blueprints, superior programs and report feedback. from parents, brave learning SIKL has advantages in terms of implementing digital systems, superior programs, as well as parental feedback reports and has shortcomings in limited internet access and student boredom in learning.
\end{abstract}

Keywords: Implementation, Online Learning, COVID-19, SIKL.

\title{
PENDAHULUAN
}

Dewasa ini, dunia dihebohkan dengan munculnya COVID-19. COVID-19 atau Coronavirus ini adalah keluarga besar virus yang menyebabkan penyakit pada manusia dan hewan. Pada manusia, biasanya menyebabkan penyakit infeksi saluran pernafasan. Mulai dari flu hingga penyakit serius seperti Middle East Respiratory (MERS) dan Sindrom Pernafasan Akut Berat atau Severe Acute Respiratory Syndrome (SARS) (Musliyadi, 2020).

Coronavirus jenis baru yang ditemukan pada manusia sejak kejadian luar biasa muncul di Wuhan, China, pada Desember 2019, kemudian diberi nama Severe Acute Respiratory Syndrome Coronavirus 2 (SARS-COV 2), dan menyebabkan penyakit Coronavirus Disease-2019 (COVID-19). Diketahui bahwa transmisi virus ini melalui manusia ke manusia. Penyebarannya begitu masif hingga telah ditemukan 1.317.130 kasus terkonfirmasi di 212 negara di dunia per 8 April 2020, termasuk di dalamnya adalah Kuala Lumpur, Malaysia (Aisyah, dkk., 2020: 29). Dilansir dari COVID-19 Data Repository by the Center for System Science and Engineering (CSSE) AT John Hopkins University (2020) terkonfirmasi bahwa terdapat Warga Negara Malaysia yang 
positif COVID-19. Hingga 21 Desember 2020, telah ditemukan 93.309 kasus positif, 437 meninggal dan 77.309 sembuh.

Adanya pandemi COVID-19 berdampak pada segala aspek kehidupan, mulai dari ekonomi, sosial, budaya, begitu pula dengan pendidikan. Imbas dari diberlakukannya physical distance atau yang semula disebut social distance salah satunya diberlakukan work form home dan learn from home. Pembatasan social atau fisik yang diputuskan oleh pemerintah menuntut proses pendidikan diberlakukan secara daring oleh pendidik dan peserta didik yang dilakukan di tempat tinggal masing-masing melalui aplikasi tertentu yang telah disepakati. (Rahmawati \& Evita, 2020)

Tidak sedikit sekolah yang cepat merespon instruksi pemerintah, termasuk juga sekolah Indonesia yang berada di luar negeri. Sekolah Indonesia Kuala Lumpur merupakan salah satu Sekolah Indonesia Luar Negeri yang juga menerapkan pembelajaran secara daring. Pembelajaran daring merupakan proses kegiatan pembelajaran yang dilakukan tanpa tatap muka secara langsung antara guru dan siswa melainkan dengan memanfaatkan platform sebagai perantara terjadinya kegiatan pembelajaran jarak jauh melalui akses jaringan internet. (Oktavia, 2020) Walaupun pembelajaran peserta didik yang masih duduk dibangku sekolah tidak bisa tatap muka secara langsung. Diharapkan pembelajaran daring dapat mendorong siswa tertantang dengan hal-hal baru yang bisa diperoleh selama proses belajar, baik teknik interaksi dalam pembelajaran maupun penggunaan media-media pembelajaran yang beraneka ragam (Albert, 2020). Hal tersebut dilaksanakan agar terputusnya mata rantai virus yang digadang-gadang oleh pemerintah dapat terealisasi dengan baik. Pendidikan dan pendampingan yang semula dilakukan oleh seorang guru atau pendidik, kini beralih tangan kepada orang tua. Adanya pandemi COVID-19 ini menjadi sebuah tantangan bagi guru, siswa, dan orang tua siswa untuk ikut serta mendukung kegiatan pembelajaran di tengah pandemi agar dapat berjalan dengan lancar.

Berdasarkan penelitian yang dilakukan oleh Acep Roni Hamdani dan Asep Priatna (2020) dengan meneliti delapan indikator menghasilkan sekitar 66,97\% tingkat efektifitas pembelajaran daring pada jenjang SD di Kabupaten Subang yang mana dari presentase tersebut perlu ditingkatkan kembali agar kualitas pembelajaran serta hasil belajar siswa mengalami peningkatan. 
Berdasarkan hasil penelitian "Dampak COVID-19 Terhadap Implementasi Pembelajaran Daring Di Sekolah Dasar" dijelaskan bahwa kerjasama antara guru, peserta didik dan orang tua sangat dibutuhkan untuk memotivasi, mengawasi, serta mengontrol kegiatan belajar anak selama di rumah agar terlaksana dengan baik. Selain itu kreatifitas guru dalam merancang pembelajaran sedemikian rupa serta penyampaiannya juga perlu diperhatikan agar kegiatan belajar selama dirumah dapat berjalan secara optimal dan efektif. (Wahyu, 2020: 60)

Tak hanya itu, dalam penelitian "Analisis Proses Pembelajaran Dalam Jaringan (Daring) Masa Pandemi COVID-19 Pada Guru Sekolah Dasar" dijelaskan bahwa hadirnya pandemi COVID-19 memberikan dampak yang signifikan dalam proses pembelajaran, yang awalnya dilakukan secara konvensional dialihkan menjadi pembelajaran daring. Adanya transformasi pembelajaran tersebut dalam pelaksanaannya tidak dipungkiri memiliki faktor pendukung sekaligus penghambat. Ketersediaan smartphone, kuota dan jaringan internet yang stabil menjadi faktor pendukung kelancaran pembelajaran daring, namun ada juga siswa pada jenjang SD yang belum memiliki smartphone dan minimnya peran orang tua dalam mendampingi serta memberikan dorongan kepada anak selama belajar di rumah. (Hilna, dkk., 2020)

Adanya tranformasi dari pembelajaran langsung yang beralih ke pembelajaran daring memberikan dampak positif hingga dampak negatif. Guru dituntut untuk dapat merencanakan serta mempersiapkan pembelajaran sebaik dan sekreatif mungkin dalam memberikan suatu materi. Sedangkan orang tua juga berperan dalam mendampingi belajar anak. Antara guru dan orang tua harus mampu bekerjasama untuk mewujudkan pembelajaran yang efektif walaupun di tengah pandemi COVID19.

Berdasarkan permasalahan diatas, tujuan dari penelitian ini adalah untuk mengidentifikasi implementasi pembelajaran daring di SIKL masa pandemi COVID19 , terobosan-terobosan yang dilakukan hingga kelebihan dan kekurangan dalam pelaksanaannya selama siswa belajar di rumah.

\section{METODE PENELITIAN}

Metode yang digunakan adalah metode kualitatif dengan studi kepustakaan (Library Research) karena menganalisis dari sumber-sumber yang diperoleh melalui surat kabar, jurnal, serta buku-buku. Penulisan artikel ini menggunakan teknik pengumpulan data melalui dokumentasi dan wawancara dengan guru dan kepala 
sekolah selama KKL International Virtual Fieldwork Study di Sekolah Indonesia Kuala Lumpur yang diselenggarakan oleh Institut Agama Islam Negeri Kudus (IAIN Kudus) dan setelahnya. Subyek dalam penelitian ini adalah guru dan kepala sekolah di SIKL. Dengan metode ini diharapkan dapat mengetahui implementasi pembelajaran daring di SIKL masa pandemi COVID-19.

\section{PEMBAHASAN}

\section{Sistem Pembelajaran Daring Sebagai Upaya Belajar di Rumah Masa Pandemi COVID-19}

Wabah COVID-19 yang telah mendunia memaksa seluruh lapisan masyarakat untuk membatasi diri keluar dari rumah. Pemerintah menerapkan kebijakan pematuhan protokol kesehatan dan menjaga jarak untuk memutus penyebaran COVID-19. (Lia, 2020) Tidak dipungkiri hal ini juga berlaku dalam dunia pendidikan. Dalam hal ini, sekolah ditutup sementara hingga keadaan membaik. Kondisi ini membuat seluruh komponen pendidikan melakukan upaya agar pembelajaran dapat berlangsung selama pandemi COVID-19 dengan menginovasi pembelajaran jarak jauh melalui daring atau pembelajaran dalam jaringan. Pembelajaran daring dilakukan dengan menggunakan perangkat teknologi dan menuntut kreativitas serta keterampilan guru dalam penggunaannya. (Abd Rahim, 2020)

SIKL telah mengklasifikasi siswa dan guru menjadi dua kategori yakni, Highrisk dan Lowrisk terhadap penyebaran Covid-19. Siswa yang tergolong highrisk, pergi dan pulang sekolah menggunakan transportasi umum sehingga memiliki resiko tinggi terpapar COVID-19. Dan siswa yang tergolong lowrisk memiliki resiko rendah terpapar COVID-19 karena menggunakan transportasi pribadi atau memiliki rumah yang jaraknya dekat dengan sekolah. Dengan adanya dua kategori tersebut, SIKL melaksanakan proses kegiatan Belajar Di Rumah (BDR) dengan sistem pembelajaran daring.

Kegiatan Belajar Di Rumah (BDR) mengharuskan guru untuk menyiapkan perangkat pembelajaran yang memungkinkan siswa untuk belajar di rumah, Untuk itu, guru harus mengubah strategi belajar mengajarnya Penggunaan metode pengajaran tepat dan keterampilan guru dalam mengelola proses pembelajaran sangat dibutuhkan selama program Belajar Di Rumah (BDR) berlangsung. Hal ini dilakukan untuk memberikan akses pembelajaran yang tidak terbatas ruang dan waktu kepada 
ट2 | Tarbawi : Jurnal Pendidikan Islam Vol. 18. No. I. Januari - Juni 202I

siswa selama diberlakukannya pembelajaran daring dari rumah di masa pandemi COVID-19. (Asrilia, dkk., 2020)

Pemanfaatan sistem pembelajaran daring merupakan upaya agar siswa dapat belajar dengan pelaksanaan yang sistematis dan pengarahan dari guru selama dirumah. Siswa dapat mengakses materi pembelajaran, saling berkomunikasi dan berdiskusi secara online dengan akses jaringan internet. (Andi, 2020).

Pembelajaran daring dapat mendorong siswa tertantang dengan hal-hal baru yang bisa diperoleh selama proses belajar, baik teknik interaksi dalam pembelajaran maupun penggunaan media-media pembelajaran yang beraneka ragam. Seperti menggunakan aplikasi edmodo, google meet, v class, zoom maupun lewat youtube live yang digunakan saat pembelajaran daring. ( Meda, dkk., 2020).

Pembelajaran secara daring sebenarnya tidak mudah dilakukan. Interaksi antara guru dan siswa yang tidak dapat dilakukan secara langsung (face to face) sehingga komunikasi yang terjalin sangatlah terbatas, Keterbatasan tersebut menyebabkan pemerolehan informasi dan instruksi dari guru kurang tersampaikan secara optimal. (I Putu \& I Made, 2020)

.Untuk menjadikan pembelajaran daring berjalan sukses maka ada tiga hal yang perlu diperhatikan yaitu Pertama, teknologi secara khusus pengaturan jaringan harus memungkinkan untuk terjadinya pertukaran sinkronisasi dan asinkronisasi, peserta didik harus memiliki akses yang mudah. Kedua, karakteristik pengajar yang mampu memainkan peran sentral agar peserta didik memiliki sifat positif terhadap pendistribusian suatu pembelajaran dan memahami akan sebuah teknologi serta bisa cenderung menghasilkan suatu pembelajaran yang lebih positif atau baik. Ketiga, karakteristik peserta didik yang cerdas, disiplin dan memiliki rasa percaya diri yang tinggi akan mampu untuk melakukan pembelajaran dengan metode daring. (Roman, 2019)

Panduan untuk melaksanakan pembelajaran daring dirumuskan dalam $5 \mathrm{M}$ yaitu memanusiakan hubungan, memahami konsep, membangun keberlanjutan, melatih tantangan, dan memberdayakan konteks. (Murhadi \& Ponidi, 2020) Pelaksanaan pembelajaran daring harus dirancang sesuai dengan kondisi siswa agar proses pembelajaran berjalan dengan baik. Selain itu pengawasan dan pendampingan orang tua juga dibutuhkan untuk menunjang kegiatan anak selama belajar di rumah.

Pembelajaran Daring Masa Pandemi Covid-19 di Sekolah Indonesia Kuala Lumpur | Titania Putri Widianti1), Silfiyani Musoffa, Muhammad Irfan Maulana, Anik Sri Widayati, \& Riza Zahriyal Falah $\mid<$ 


\section{Implementasi pembelajaran daring di SIKL}

Dampaknya COVID-19 yang menyebar dipenjuru Negara begitu besar konsekuensi bagi pendidikan untuk memutuskan rantai penularan virus tersebut, yang awal mula pembelajaran dengan tatap muka di sekolah sekarang menjadi belajar dirumah dengan menggunakan berbagai aplikasi digital. Begitu pula pada Sekolah Indonesia Kuala Lumpur yang merupakan salah satu tempat mendidik generasi muda anak Indonesia yang menetap di Negara Malaysia, dengan selalu memperhatikan garda terdepan diplomasi pendidikan dengan konteks didasarinya Pancasila dan Undang-undang Dasar 1945.

Masih terdapat beberapa sekolah yang belum dapat menyelenggarakan KBM daring di awal mula munculnya virus ini, namun dengan perkembangan dan adaptasi baru menjadikan pembelajaran berbasis daring bisa terkendalikan secara terstruktur yang didalam pembelajaran ini seorang guru dituntun untuk mengembangkan kreativitas di media alternatif selama siswa belajar di rumah (Sobron, dkk., 2019: 3536). Sesuai dengan kesepakatan pemerintahan di Indonesia, Menteri Nadiem Anwar Makarim menerbitkan Surat Edaran Nomor 3 Tahun 2020 pada Satuan Pendidikan dan Nomor 36962/MPK.A/HK/2020 tentang Pelaksanaan Pendidikan dalam Masa COVID-19 maka pada proses kegiatan belajar dilakukanm secara daring (online) dalam rangka pencegahan adanya penyebaran virus COVID-19 (Menteri Pendidikan, 2020). Dari hal ini SIKL juga menyesuaikan dengan kesepakatan pemerintahan di Indonesia dan pemerintahan Malaysia sebagai tempat untuk belajar anak Indonesia yang menetap di Negara tersebut. Didalam pembelajaran SIKL mengikut sertakan penggunaan teknologi digital, dengan selalu pemantauan pendampingan oleh guru. Kemudian guru juga berkoordinasi dengan orang tua untuk memastikan adanya pembelajaran di rumah berjalan dengan lancar.

Kemampuan literasi digital di SIKL dalam kemampuannya untuk mendapatkan, memahami, dan menggunakan informasi dari berbagai sumber bentuk digital kemudian dijadikan sistematika berbasis pencapaian kompetensi siswa diberlakukannya Belajar Di Rumah (BDR), dengan memberikan pelayanan belajar secara optimal dalam penggunaan IT terhadap kegiatan belajar. Bentuk implementasi yang dilaksanakan sekolahan tersebut, memberikan penegasan secara intelektual bahwasanya pembelajaran daring ini sebagai proses beradaptasi dengan teknologi bagi siswa. Sesuai dengan penelitian sebelumnya Acep Roni Hamdani dan Asep Priatna (2020: 5), dengan hal ini siswa tidak perlu berangkat sekolah, namun dapat 
langsung melalui online ketika belajar. Bahkan di situasi ini, teknologi menjadi penghubung di setiap proses pembelajaran.

Teknik dalam pembelajaran saat kondisi pandemi ini tidak berbeda jauh yang ada di Indonesia, yang dimana sistematikanya terprogramkan secara daring, dan mengenai sarana serta prasarana yang digunakan di SIKL sangat memadai, seperti laptop, komputer, smartphone, dan jejaringan internet. Berdasarkan pembahasan yang dikemukakan oleh Albert Efendi Pohan (2020), Pembelajaran siswa saat dirumah harus diikut sertakan peran orang tua dalam mendampingi serta membekali sikap tanggung jawab dan karakter siswa. Secara umum setiap pendekatan pembelajaran serta pendampingan yang dilakukan guru serta orang tua bertujuan pula untuk mengembangkan aspek-aspek yang perlu ditanamkan kepada siswa, diantaranya aspek pengetahuan, keterampilan, dan sikap. Dengan pemerolehan tersebut, maka sejatinya adanya proaktif, produktif, inovatif, kreatif, dan afektif. Dengan hal demikian SIKL juga menerapkan sistem program yang membentuk kerjasama anatar guru dengan orang tua.

Disetiap penerapan yang terjadi pada pembelajaran daring tersebut, SIKL memberlakukan kebijakan feedback laporan orang tua kepada guru atas pencapaian siswa selama belajar di rumah. Dukungan dari orang tua siswa, mampu memunculkan progress baik pada pelaksanaan BDR dengan bukti pendampingan, baik dengan peran memotivasi anak, memfasilitasi, menumbuhkan kreativitas, mengawasi dalam belajar, dan mengevaluasi belajar anak (I Ketut Sudarsana, dkk., 2020: 76). Disinilah peran kolaborasi antara guru dengan orang tua dalam pendukung tercapainya proses belajar daring (online). Adanya pendampingan dan keaktifan orang tua dalam menemani anak mengenai sejauh mana kegiatan belajar di rumah dengan harapan setiap progres belajarnya nanti dapat membentuk karakter serta meningkatkan mutu siswa di dunia pendidikan, dan tanggap dalam menciptakan karya sebagai bentuk implementasi belajar. Dari hal ini pula, setiap gerakan apresiasi guru dan orang tua dalam menjalankan tugas sebagai tokoh mendidik kualitas belajar siswa, menghasilkan ketercapaian tujuan pembelajaran sesuai apa yang telah ditentukan (Falih Suaedi, 2019).

Pengevaluasian di SIKL dapat dilihat dari pemrograman BDR tersebut pada setiap tingkatan, seperti Tingkatan Taman Kanak-kanak (TK) dan siswa kelas 1-3 Sekolah Dasar (SD) tidak diadakannya ulangan ataupun ujian akhir setiap semester, dikarenakan pada tingkatan tersebut masih diberikannya pembelajaran yang 
terfokuskan pada penanaman nilai karakter. Sedangkan pada tingkatan atasnya (SD kelas 4-6, SMP, dan SMA) diberlakukannya ulangan maupun ujian akhir setiap semester dengan memajukan aplikasi digital, karena daya pikir siswa di jenjang tersebut lebih serius untuk mencapai progress yang diinginkan dan dituju.

Pemrograman di SIKL selain adanya kolaborasi guru dengan orang tua, perlu diperhatikan pula mengenai blueprint/lessonbuidance yang merupakan suatu deskripsi secara mendetail dalam seperangkat perancanaan dengan strategi yang akan dilakukan guna pencapaian visi tujuan pembelajaran. Dari istilah blueprint ini memberikan pemunculan baru di SIKL mengenai kesiapan guru dalam mempersiapkan kegiatan belajar mengajar dengan selalu memperhatikan metode, model, dan kompenen lainnya dari jenjang TK hingga SMA. Bentuk penerapan blueprint di SIKL saat COVID-19 yaitu adanya kegiatan belajar online dengan mengembangkan digitalisasi sistem dan media pembelajaran. Dengan kemajuan metode dan IT yang ada di SIKL ini guru dituntut harus menguasai penuh pada bagian materi, metode dan IT.

Bentuk upaya penerapan pembelajaran online yang telah terealisasi oleh progam-progam digital yang meliputi RPP digital, SIKL Channel TV, dan Teacher Media Digital. Dari pemrograman perangkat aplikasi tersebut telah memberikan kemudahan dalam pengaksesan materi dengan kualitas yang memumpuni untuk bukti adanya inovasi serta kreasi dalam perangkaian media pembelaran. Bentuk kreativitas guru dalam menghadirkan pembelajaran online yang menarik dapat menentukan besarnya atensi siswa terhadap kegiatan belajar (I Ketut Sudarsana, dkk., 2020).

Setiap pelayanan dalam mendidik siswa, juga akan lebih mudah tersampaikan dengan serangkaian media pembelajaran dengan pemrograman unggulan yang berbasis digital tersebut. Dari sekian literatur digital terhadap pendidikan anak di tengah pandemi Covid-19 memiliki peran penting dalam dunia pendidikan. Pada literature digital tersebut diperoleh dari berbagai sumber yang luas serta telah dikonversikan, sehingga siswa dapat belajar di rumah. Anjuran pemerintah untuk selalu stay at home, physical dan social distancing harus dilaksanakan dengan adanya perubahan belajar tatap muka menjadi online, sesuai dengan pemerintahan di Indonesia maupun Malaysia (Ali \& Afreni, 2020). Dengan demikian penerapan pembelajaran daring di SIKL yang menggunakan program digital. Diberlakukannya belajar di rumah tersebut, tujuan intinya yang tidak lain adalah agar terputusnya 
26 | Tarbawi : Jurnal Pendidikan Islam Vol. 18. No. I. Januari - Juni 202I

penyebaran rantai virus COVID-19 sesuai dengan kesepakatan dari semua pihak pemerintah Indonesia, Malaysia, maupun Negara-negara lainnya.

\section{Kelebihan Dan Kekurangan Pembelajaran Daring di SIKL.}

Pelaksanaan pembelajaran daring masa pandemi COVID-19 di SIKL memiliki kelebihan, diantaranya yaitu:

\section{a. Guru menjadi lebih kreatif}

Dalam melaksanakan kegiatan mengajar di tengah pandemi COVID-19, guru di SIKL menjadi lebih kreatif. Dapat dilihat dari trobosan kepala sekolah SIKL dalam menerapkan Teacher Media Digital bagi para guru di SIKL. Bentuk kreativitas guru dapat dilihat dari adanya inovasi serta kreasi dalam perangkaian media belajar. Guru di SIKL dituntut agar mampu membuat media digital dalam pembelajaran sedemikian rupa dan semenarik mungkin agar materi pembelajaran dapat disampaikan secara optimal dan dengan mudah dipahami oleh siswa,

\section{b. Adanya digitalisasi sistem melalui blueprint}

Di SIKL terdapat digitalisasi sistem blueprint yang sifatnya menyeluruh dan terintegrasi, membantu pihak sekolah untuk menyusun rencana atau program yang terukur dalam mencapai SDM yang unggul dan mempermudah evaluasi terhadap program-program tersebut. Di tengah pandemi COVID-19 adanya blueprint juga membantu orang tua mengetahui rancangan pembelajaran yang diterapkan serta menjadikan pelaksanaan pendidikan berjalan efektif dan efisien.

\section{c. Kerjasama antara guru dengan orang tua}

SIKL menerapkan kebijakan feedback laporan dari orang tua selama siswa belajar di rumah sebagai bukti pendampingan orang tua terhadap anak. Hal ini menjadikan komunikasi antara guru dan orang tua lebih intens, bekerjasama untuk mensukseskan pembelajaran yang dilakukan selama di rumah. Antara guru dan orang tua dapat menyamakan persepsi dan pandangannya, serta melakukan upaya yang baik agar proses pembelajaran dapat berjalan dengan lancar.

\section{d. Adanya program-program digital yang memadai}

Di SIKL terdapat beberapa program digital seperti RPP Digital, SIKL Channel TV, dan Teacher Media Digital. Program-program tersebut memberikan kemudahan bagi guru dan siswa dalam melaksanakan pembelajaran di tengah pandemi COVID19. 
Dengan belajar dirumah atau via daring tentunya memilki tantangan. Berbagai tantangan yang dihadapi selama pembelajaran via daring meliputi :

\section{a. Keterbatasan kuota internet bagi siswa}

Dalam pembelajaran via online ini pastinya para siswa memerlukan kuota intetrnet untuk menyimak materi yang disampaikan guru. Seperti di Indonesia yang sistem pembelajarannya 5 hari kerja otomatis hampir setiap hari memerlukan internet.

\section{b. Kendala dalam jaringan}

Tentunya dimasa pandemi corona ini semua serba digital, termasuk pembelajaran di SIKL ini yang menggunakan pembelajaran via online. Tentunya baik guru maupun siswa di SIKL ini menggunakan koneksi internet untuk menunjang pembelajaran via online ini, selain kuota internet membutuhkan juga jaringan koneksi internet untuk kelangsungan pembelajaran ini. Ketika guru menjelaskan materi siswa tidak mungkin juga langsung memahami materi yang diberikan karena terhambat koneksi internet yang terkadang suara yang terputus-putus, dan stidak semua siswa dapat fokus memperhatikan penjelasan yang disampaikan.

\section{c. Sikap siswa yang bosan}

Karena suasana yang sangat berbeda dengan kebiasaan disekolah bercengkrama dengan teman-teman dan sekarang harus dirumah dan melakukan pembelajaran via daring. Untuk itu, disini orang tua berperan untuk memberi motivasi dan bimbingan siswa agar senantiasa bersemangat dalam melaksanakan kegiatan pembelajaran via daring.

\section{d. Peserta didik kurang aktif atau kurang tertarik dengan pembelajaran daring}

Meskipun mereka didukung dengan fasilitas yang memadai dari segi ketersediaan perangkat komputer, handphone/gadget, dan jaringan internet. Kurangnya kepedulian akan pentingnya literasi dan pengumpulan tugas portofolio, sering menghambat jalannya BDR. Tugas yang seharusnya dikumpulkan dalam tenggang waktu satu minggu sering molor menjadi dua minggu.

\section{e. Tidak semua siswa memiliki gadged}

Penggunaan gadged disini sebagai media belajar daring, masih banyak kita jumpai siswa yang belum memiliki gadged, kalaupun ada milik orang tua mereka. mendapat giliran setelah orangtua pulang kerja. Ada yang pulang di siang hari, sore hari, bahkan malam hari. Sementara itu umumnya jadwal pembelajaran daring di sekolah dilakukan mulai pagi hari hingga siang hari. (Asmuni. 2020: 284-285). 


\section{SIMPULAN}

Dari hasil analisis yang dilakukan peneliti tentang pembelajaran daring masa pandemi COVID-19 di Sekolah Indonesia Kuala Lumpur dapat disimpulkan bahwa sistem pembelajaran daring menjadi alternatif saat belajar di rumah (BDR) sebagai bentuk ikhtiar untuk memutus penyebaran COVID-19. Pembelajaran daring membutuhkan kreativitas guru dalam merancang media untuk kegitan mengajar siswa dan peran orang tua mendampingi siswa belajar di rumah.

Implementasi pembelajaran daring di SIKL adalah dengan adanya sistem digital seperti blueprint, program unggulan dan feedback laporan dari orang tua. Blueprint digunakan untuk pencapaian visi tujuan pembelajaran dan kesiapan guru dalam mempersiapkan kegiatan belajar mengajar dengan selalu memperhatikan metode, model, dan kompenen lainnya. Terdapat juga progam-progam digital yang meliputi RPP digital, SIKL Channel TV, dan Teacher Media Digital yang memberikan kemudahan dalam pengaksesan materi dengan kualitas yang memumpuni sebagai bukti adanya inovasi serta kreasi dalam perangkaian media pembelaran. Feedback laporan dari orang tua digunakan untuk mengetahui kegitan belajar anak di rumah melalui pendampingan orang tua.

Pelaksanaan pembelajaran daring di SIKL memiliki kelebihan dari programprogam yang disediakan, selain meningkatkan kreativitas guru. kebijakan seperti feedback dari orang tua menjadi perantara komunikasi lebih dekat antara guru dengan orang tua siswa dalam kegiatan belajar anak belajar di rumah selama pandemi COVID-19. Disamping kelebihan, terdapat juga kekurangan dalam akses internet, kurangnya fasilitas yang tersedia di rumah, serta adanya rasa jenuh yang dialami oleh siswa.

Di tengah pandemic COVID-19, kegiatan pembelajaran memerlukan usaha yang ekstra agar tetap berjalan secara optimal. Salah satu yang harus dilakukan adalah membuat trobosan dan inovasi dalam pembelajaran melalui program-program belajar. Program-progam yang diterapkan dalam SIKL dapat dijadikan sebagai wawasan bagi pendidikan di Indonesia agar lebih efektif dan efisien dalam pelaksanaannyaserta bangkit dari ketertinggalan untuk meningkatkan kualitas pendidikan di Indonesia

\section{DAFTAR PUSTAKA}

Amelia, A., Hasanah, U., Rahman, H., \& Putra, A. M. (2020). Analisis Keefektifan Pembelajaran Online Di Masa Pandemi COVID-19. Mahaguru: Jurnal 
Pendidikan Guru Sekolah Dasar, 2 (1). https://ummaspul.ejournal.id/MGR/article/download/559/313.

Anugrahana, Andi. (2020). Hambatan, Solusi dan Harapan: Pembelajaran Daring Selama Pandemi COVID-19 Oleh Guru Sekolah Dasar, 10 (3). https://ejournal.uksw.edu/scholaria/article/view/4033.

Asmuni. (2020). Problematika Pembelajaran Daring Di Masa Pandemi COVID-19 Dan Solusi Pemecahannya. Jurnal Paedagogy: Jurnal Penelitian Dan $\begin{array}{ll}\text { Pengembangan } & \text { Pendidikan, }\end{array}$

http://ojs.ikipmataram.ac.id/index.php/pedagogy/artoc;e/view/2941.

Atiqoh, Lia Nur. (2020). Respon Orang Tua Terhadap Pembelajaran Daring Pada Masa Pandemi COVID-19. Thufuli: Jurnal Pendidikan Islam Anak Usia Dini, 2 (1). http://www.riset.unisma.ac.id/index.php/thufuli/article/view/6925.

Dewi, Wahyu Aji Fatma. (2020). Dampak COVID-19 Terhadap Implementasi Pembelajaran Daring Di Sekolah Dasar. Edukatif: Jurnal IImiah Pendidikan, 2 (1). https://www.edukatif.org/index.php/edukatif/article/view/89.

Hamdani, A. R., \& Priatna, A. M. (2020). Efektifitas Implementasi Pembelajaran Daring (Full Online) Dimasa Pandemi COVID-19 Pada Jenjang Sekolah Dasar Di Kabupaten Subang. Didaktik: Jurnal IImiah PGSD STKIP Subang, 6 (1). http://journal.stkipsubang.ac.id/index.php/didaktik/article/view/120

Handarini, O. I., Wulandari, S. S. (2020). Pembelajaran Daring Sebagai Upaya Study From Home (SFH) Selama Pandemi COVID-19. Jurnal Pendidikan $\begin{array}{llll}\text { Administrasi } & \text { Perkantoran } & \text { (JPAP), }\end{array}$ https://journal.unesa.ac.id/index.php/jpap/article/view/8503.

Kurniasari, A., Pribowo, F. S. P., Putra, D. A., Analisis Efektivitas Pelaksanaan Belajar Dari Rumah (BDR) Selama Pandemi COVID-19. Jurnal Review Pendidikan Dasar: Jurnal Pendidikan Dan Hasil Penelitian, 6 (3). https://journal.unesa.ac.id/index.php/PD/article/view/10423.

Mansyur, Abd Rahim. (2020). Dampak COVID-19 Terhadap Dinamika Pembelajaran Di Indonesia. Education and Learning Journal, 1 (2). http://jurnal.fai.umi.ac.id/index.php/eljour/article/view/55/0.

Menteri Pendidikan. (2020). Surat Edaran Nomor 3 Tahun 2020 Tentang Pelaksanaan Pendidikan dalam Masa Darurat CoronaVirus (COVID-19) 
Murhadi, \& Ponidi. Pembelajaran Online Yang Efektif Di Masa Pandemi COVID-19 Studi Kasus di SMP Negeri 4 Pakem Sleman. Jurnal INTEK, 3 (1). http://jurnal.umpwr.ac.id/index.php/intek/article/view/568.

Musliyadi. (2020). Potensi Ancaman Bencana Virus Corona di Provinsi Aceh. Serambi Konstruktivis,

http://ojs.serambimekkah.ac.id/Konstruktivis/article/view/2202.

Pangondian, R.A., Santosa, P. I., \& Nugroho, Eko (2019). Faktor-Faktor Yang Mempengaruhi Kesuksesan Pembelajaran Daring Dalam Revolusi Industri 4.0: Jurnal Seminar Nasional Teknologi Komputer Dan Sains (SAINTEKS), 1 (1). https://www.prosding.seminar-id.com/index.php/sainteks/article/view/122.

Pohan, Albert Efendi. (2020). Konsep Pembelajaran Daring Berbasis Pendekatan IImiah. Purwodadi: CV Sarnu Untung.

Purandiana, I. P. Y., \& Winaya, I. M. A. Pendidikan Karakter di Lingkungan Keluarga Selama Pembelajaran Jarak Jauh Pada Masa Pandemi COVID-19. Cetta: Jurnal Ilmu Pendidikan, 3 $3 \quad(2)$. http://jayapanguspress.penerbit.org/index.php/cetta/article/view/454.

Putria, Hilna, Maula, L. H., \& Uswatun, D. A. (2020). Analisis Proses Pembelajaran Dalam Jaringan (Daring) Masa Pandemi COVID-19 Pada Guru Sekolah Dasar. Jurnal Basicedu, 4 (4). http://jbasic.org/index.php/basicedu/article/view/460.

Rahmawati, R., \& Putri, E. M. I. (2020). Learning From Home Dalam Perspektif Persepsi Mahasiswa Era Pandemi COVID-19. In Prosiding Seminar Nasional Hardiknas.

http://proceedings.ideaspublishing.co.id/index.php/hardiknas/article/view/3.

Sadikin, A., \& Hamidah, A. (2020). Pembelajaran Daring di Tengah Wabah Covid-19. Biodik: Jurnal Ilmiah Pendidikan Biologi, 2 (6). https://onlinejournal.unja.ac.id/biodik/article/view/9759.

Sobron, A. N., \& Bayu, R. (2019). Persepsi Siswa Dalam Studi Pengaruh Daring Learning Terhadap Minat Belajar IPA. Scaffolding: Jurnal Pendidikan Islam Dan Multikulturalisme, 2

https://ejournal.insuriponorogo.ac.id/index.phpscaffolding/article/view/117.

Suaedi, Falih. (2019). Dinamika Manajemen Strategi Sektor Publik di Era Perubahan. Surabaya: Bening Pustaka. 
Sudarsana, I. K., Lestari N. G. A. M. Y., Wijaya, I. K. W. B., Krisdayanthi, A., Andayani, K. Y., Trisnadewi, K., \&.Kusmawati, N. A. (2020). COVID-19: Perspektif Pendidikan. Bandung: Yayasan Kita Menulis.

Yuliana, M., Simarmata, J., Susanti, S. S., Mahawati, E., Sudra, R. I., Dwiyhanto, H, Irawan, E., Ardiana, D. P. Y., Muttaqin, \& Yuniawati, I. (2020). Pembelajaran Daring Untuk Pendidikan Teori dan Pendidikan. Yayasan Kita Menulis. 